Int. J. Dev. Biol. 53: 1541-1547 (2009)

doi: $10.1387 / \mathrm{ijdb} .072410 \mathrm{mn}$

\title{
Epithelial-Mesenchymal Transitions in development and disease: old views and new perspectives
}

\author{
M. ANGELA NIETO* \\ Instituto de Neurociencias, CSIC-UMH, San Juan de Alicante, Spain
}

\begin{abstract}
The epithelial to mesenchymal transition (EMT) is a fascinating phenotypic change that is undertaken by embryonic and adult cells in physiological and pathological conditions, respectively. This change in cell behavior involves the loss of epithelial characteristics and the acquisition of migratory properties. While it has long been established as a fundamental process in the generation of many different embryonic tissues, its significance during tumor progression as an initial determining step in the metastatic cascade has remained a matter of debate. Recent molecular analyses coupled with state-of-the-art imaging technology have helped to define the EMT as an important landmark, not only during tumor progression, but also during the development of other pathologies such as organ fibrosis. Spanish groups have contributed to the analysis of EMT both from the developmental and the pathological point of view, in particular assessing the implication of the Snail genes in this process. Interestingly, the contribution of Spanish scientists to the existence of EMT in tumors possibly goes back more than 100 years, when Cajal referred to some "pear-like cells, not attached to each other" in his description of human breast carcinomas.
\end{abstract}

KEY WORDS: snail transcription factors, EMT, cell migration

\section{The EMT in embryonic development}

The epithelial to mesenchymal transition (EMT) involves profound changes in the morphology and behavior of epithelial cells. Not only do epithelial cells loose contact with their neighbors but they also become motile and can break through the basement membrane that separates different tissues within the embryo. Decades ago, embryologists rapidly became aware of this transformation (Hay, 1968; Thiery, 1984; Bellairs, 1987; Hay, 1989) in part because EMT occurs repeatedly during embryonic development for the generation of tissues and organs whose precursors originate far from their final destination. EMT is necessary for the embryo to allow epithelial cells to migrate over what may be very long distances. It is important to note that EMT refers to epithelial cells that adopt a mesenchymal cell phenotype and thus, neither the process nor the molecules that trigger it (see below) are generally used to promote the movement of other cell types such as migration of neurons within the developing brain. Another interesting aspect of EMT that must be considered occurs once the cells have reached their destination, where their differentiation into different cell types very often involves the reverse process, a mesenchymal to epithelial transformation (MET). The transient nature of the transformation facilitates the formation of many different embryonic derivatives and explains why the term transition is preferred to that of transformation.

The delamination of the neural crest from the neural tube and that of the mesoderm from the primitive streak in amniotes are considered the prototypical EMTs and these events have contributed much information to understand the cellular and molecular aspects of EMT (Fig. 1A, B). These two tissues give rise to a plethora of derivatives and together, they are the precursors of the peripheral nervous system, the pigment cells, the skeleton, the muscles and components of the dermis. Moreover, the neural crest and the mesoderm are the embryonic tissues in which the Snail genes were described, among the principal inducers of EMT. In her excellent review in 1995, Elizabeth Hay proposed the existence of a master mesenchymal regulatory gene(s) that is activated to induce EMT (Hay, 1995). The Snail genes, which encode transcription factors of the zinc-finger type, have proven to behave like master genes for EMT, as they are able to induce

Abbreviations used in this paper: EMT, epithelial to mesenchymal transition; MET, mesenchymal to epithelial transition.

*Address correspondence to: M. Angela Nieto. Instituto de Neurociencias, CSIC-UMH, San Juan de Alicante, E-03550, Spain. Tel: +34-96-591-92-43. e-mail: anieto@umh.es

Final author-corrected PDF published online: 10 September 2008

ISSN: Online 1696-3547, Print 0214-6282

(C) 2009 UBC Press

Printed in Spain 
the full process both in vitro and in vivo. Accordingly, the expression of many molecules that influence both cell morphology and behavior are regulated by the Snail proteins (Fig. 2).

The first indication that Snailgenes were involved in triggering EMT came form studies in the early chick embryo. Antisense oligonucleotides against Slug (now called Snail2) prevented neural crest and mesoderm delamination (Nieto et al., 1994) and subsequently, it was confirmed that Snailgenes are crucial for the induction of EMT in different species and tissues (reviewed in Hemavathy et al., 2000; Nieto, 2002; Ip and Gridley, 2002; De Craene et al., 2005; Barrallo-Gimeno and Nieto, 2005). As such, in addition to the neural crest and the mesoderm, Snail genes participate in the EMT necessary for the formation of the heart cushions (Romano and Runyan, 2000; Carmona et al., 2000; Timmerman et al., 2004), the parietal endoderm (Velmaat et al., 2000) and the closure of the palate (Martinez-Alvarez et al., 2004; Murray et al., 2007), as well as events in other tissues and organs. Moreover, the Snail genes have been the subject of numerous evolutionary studies due to peculiarities such as the evolutionary interchange of the expression patterns of the different Snailgenes in different species, and their association with the origin of the neural crest (Sefton etal., 1998; Locascio etal., 2002; Manzanares and Nieto, 2003). Likewise the EMT has been studied across evolution given its ancestral role in triggering cell movements in Metazoa (Fritzenwanker etal., 2004). Other developmental genes that are important in EMT include the transcription factors Twist (Yang et al., 2004), E47(Pérez-Moreno et al., 2001) and Sip-1 (Comijn et al., 2001). In this review, we will focus our attention on the Snail genes since several groups working in Spain have contributed significantly to our understanding of how these genes participate in the EMT process, both during embryonic development and in the adult.

\section{The EMT in tumor progression}

As discussed in the first publication that described a relationship between Snailgenes and EMT, their pathological activation could contribute to the onset of an invasive or metastatic phenotype during the progress of epithelial cancers (Nieto et al., 1994). At the cellular level, the delamination of malignant cells from the primary tumor is reminiscent of that undertaken by neural crest cells and the mesoderm. Indeed, Snail is activated in the invasive

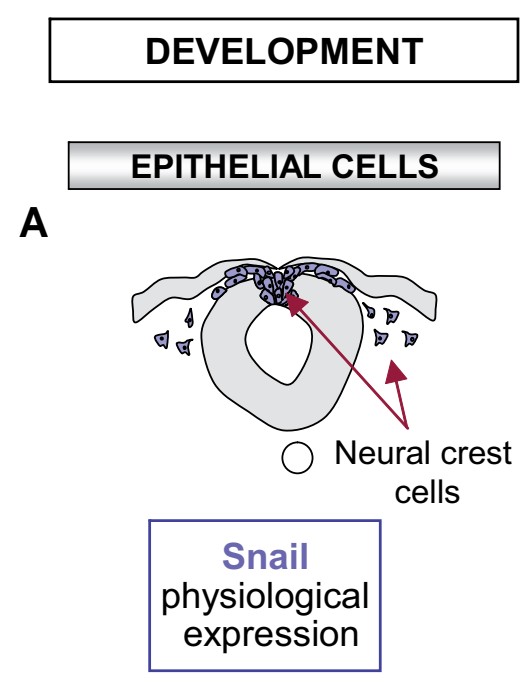

B

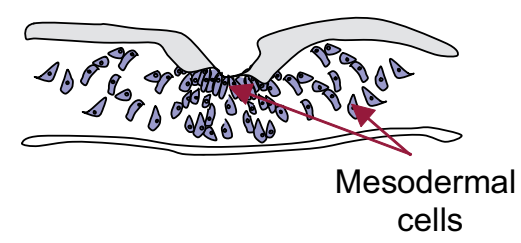

MESENCHYMAL CELLS

\section{TUMOUR PROGRESSION}

EPITHELIAL TUMOUR CELLS

C

Invasive cells Tumour cells

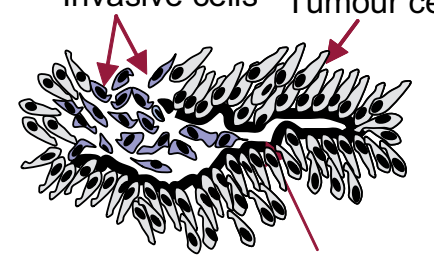

Basement membrane

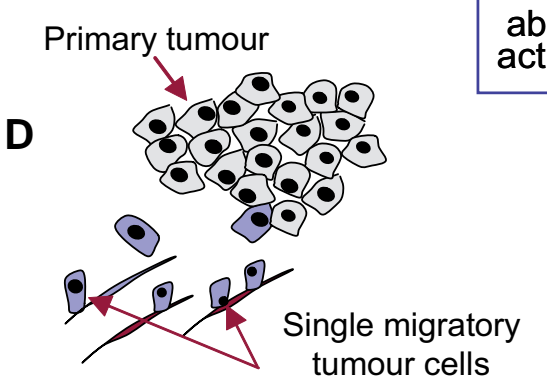

INVASIVE CELLS
FIBROSIS

\section{RENAL EPITHELIUM}

E

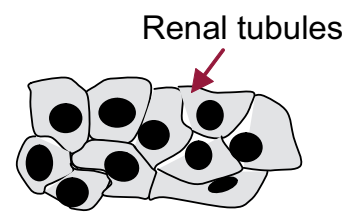

$\square$ Snail negative cells

Snail positive cells

Fig. 1. Snail and the Epithelial-Mesenchymal Transition (EMT) in health and disease. (A,B) The EMT is fundamental for the development of many tissues and organs, including the neural crest and the mesoderm of amniotes. (C) Snail is activated in vivo at the invasive front of chemically-induced mouse skin tumors and it is present in human carcinomas of different etiologies, where it is inversely correlated with the degree of differentiation and is associated with lymph-node metastasis (see Barrallo-Gimeno and Nieto, 2005, for review). (D) Multiphoton intravital microscopy has facilitated the visualization of individual primary tumor cells migrating away from the tumor mass (Wang et al., 2002). (E) Snail is maintained silent in the adult and its pathological activation in the kidney leads to renal fibrosis (Boutet et al., 2006). 


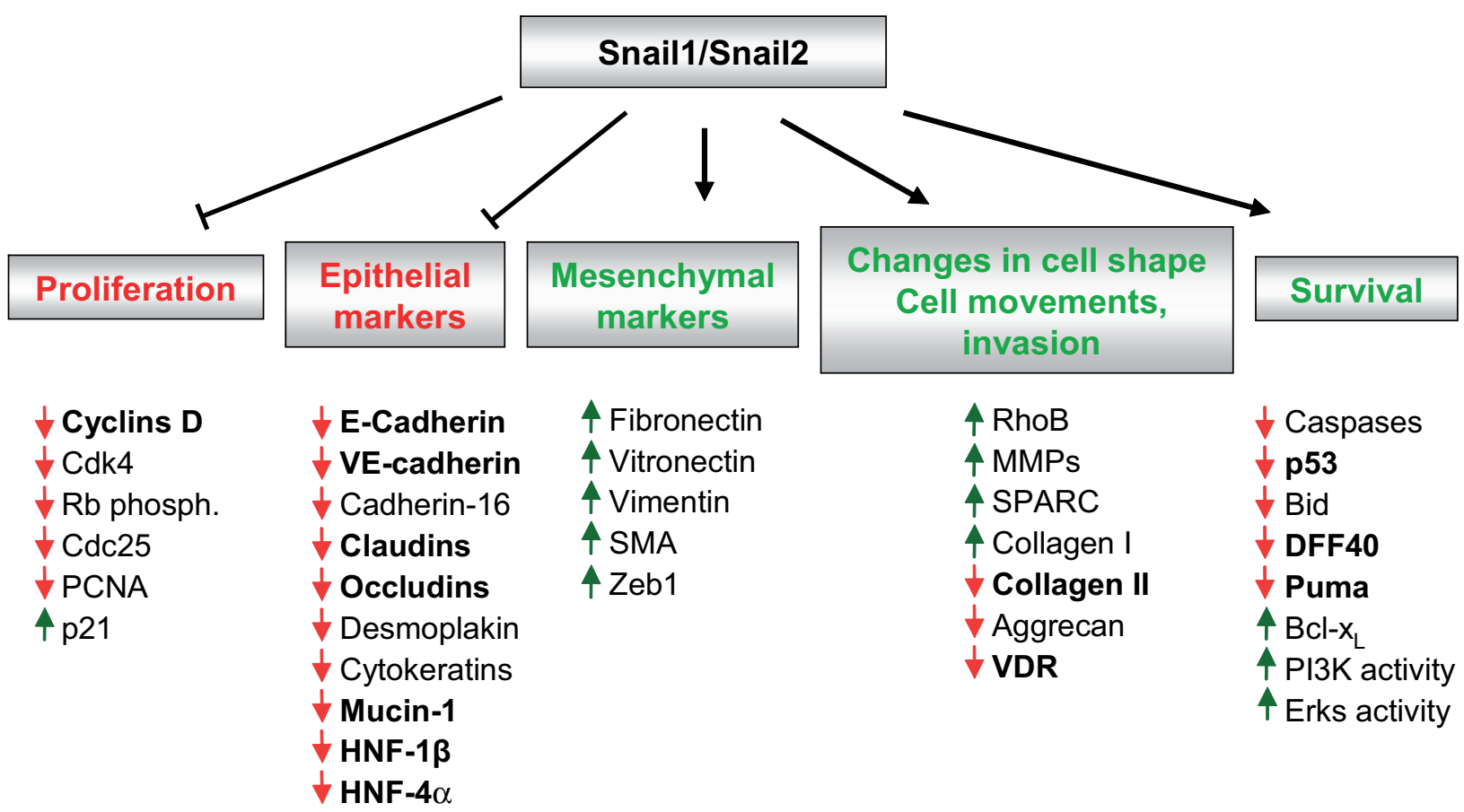

Fig. 2. Downstream targets of Snail. In addition to molecules involved in morphological changes and the acquisition of motile and invasive properties, the Snail genes also regulate cell proliferation and cell death. The targets that are directly regulated by Snail genes are shown in bold. Bid, Bclinteracting death agonist; Cdk, cyclin-dependent kinase; DFF, DNA fragmentation factor; Erks, extracellular signal-regulated kinases; HNF, hepatocyte nuclear factor; MMPs, metalloproteinases; PI3K, phosphoinositide 3-Kinase; p21, cyclin-dependent kinase inhibitor; p53, tumor suppressor; Rb, retinoblastoma; SMA, alpha smooth muscle actin; SPARC, secreted protein, acidic and rich in cysteine; VDR, vitamin D receptor. Updated from a previous version in Barrallo-Gimeno and Nieto, 2005.

areas of tumors generated in the skin of mice (Cano et al., 2000; Fig. 1C), in undifferentiated breast tumors (Blanco et al., 2002) and in other carcinomas from different etiologies (see for instance Rosivatz et al., 2002; Saito et al., 2004; Miyoshi et al., 2005; Kuphal et al., 2005; Franci et al., 2006; Boutet et al., 2007). Thus, Snail is now regarded as a marker of tumor malignancy and a target of anti-invasive drugs. Furthermore, Snail has also been implicated in the promotion of tumor recurrence (Moody et al., 2005) and regulates the expression of other molecules unrelated to EMT, such as the vitamin D receptor, with implications in cancer therapy (Palmer et al., 2004).

The molecular analysis of Snail-induced EMT showed that Snail is a strong repressor of E-cadherin transcription (Batlle et al., 2000; Cano et al., 2000), which very much influences cell behavior both in embryonic development and tumor progression. Indeed, the loss of E-cadherin expression is clinically regarded as poor prognostic sign, since it is associated with the transition to an invasive phenotype (Perl et al., 1998). In addition to Snail, other E-cadherin repressors that contribute to EMT and tumor progression have subsequently been described. These include members of the ZEB and HLH families that are differentially distributed in tumors of different origins (see Peinado et al., 2007 for a review).

It is important to note that E-cadherin repression is not sufficient to induce EMT or invasive properties, as its re-expression in mesenchymal cells does not induce the reversion to the epithelial phenotype (Navarro et al., 1993). Indeed, E-cadherin repressors, and in particular Snail, directly or indirectly regulate the expression of many additional target genes (Fig. 2) in order to repress the epithelial character and provoke the mesenchymal transition. Moreover, the different Snail family members may be functionally equivalent (Del Barrio and Nieto, 2002) and as well as their many common targets, each may also have specific targets (MorenoBueno et al., 2006).

Snail can also promote tumor progression by activating angiogenesis (Peinado et al., 2004b) and there are indications to suggest that silencing Snail can revert invasion (Olmeda et al., 2007). Recent studies are contributing to our knowledge of the mechanisms that control Snail activity as a transcription factor (Peinado et al., 2004a; Peinado et al., 2005).

Animals models generated to study the role of Snail in tumorigenesis are now available and should prove very useful to further study these processes (Perez-Mancera et al., 2005a; 2005b). However, it is important to bear in mind that these models must take into account the fundamental roles played by Snail during embryonic development, which can jeopardize such studies. In summary, EMT is an important step in the acquisition of the invasive phenotype of tumors, providing an example of an important developmental process that adopts a sinister role in the adult, as discussed by Jean Paul Thiery (Thiery, 2002).

\section{The EMT in organ fibrosis}

The sinister role of EMT in the adult is not restricted to tumor progression and indeed, adult non-transformed epithelial cells exposed to Snail undergo EMT, disrupting tissue homeostasis. Their aberrant activation in the adult kidney is sufficient to induce 

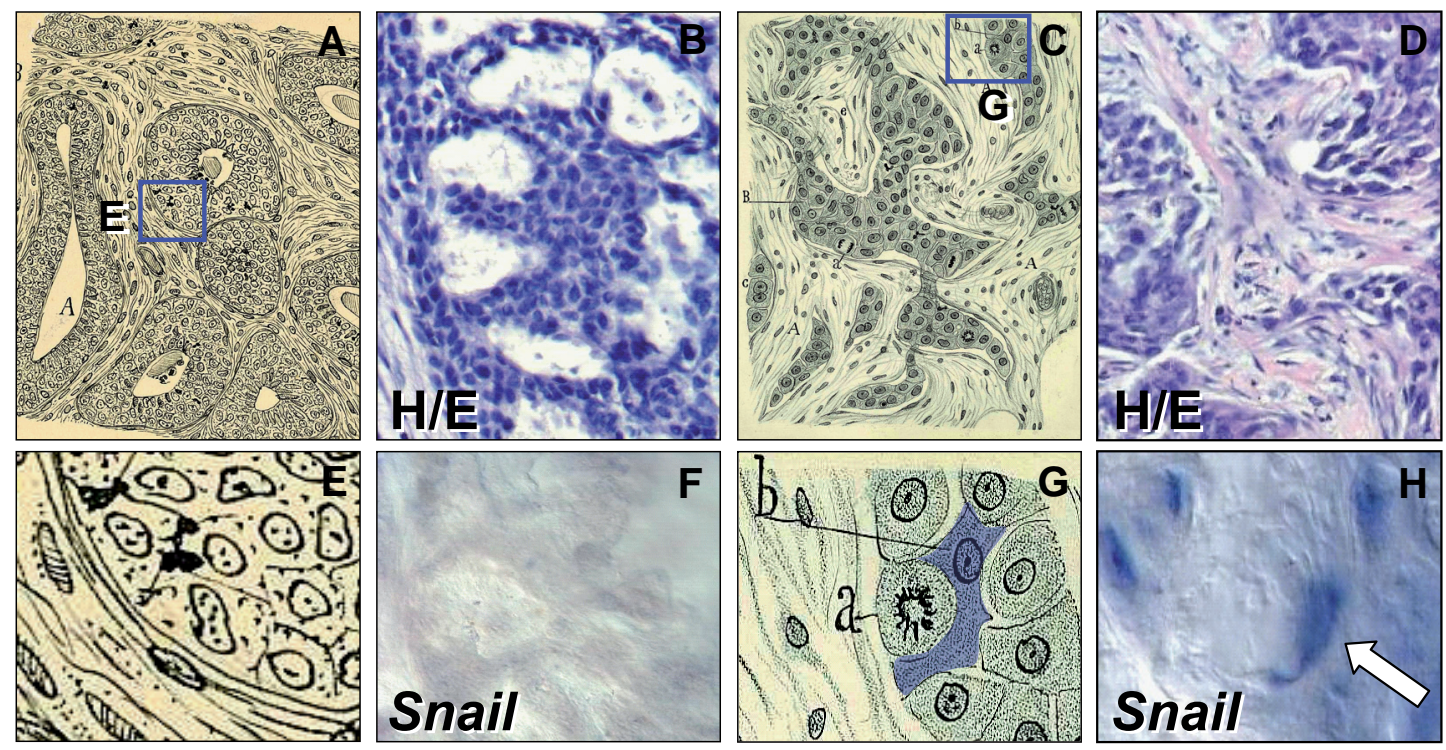

Fig. 3. From Cajal's "pear-like" cells to the Snail-expressing cells in tumors. Cajal's drawing of human breast carcinoma biopsies. (A,E) Differentiated and undifferentiated ductal breast carcinomas, respectively. (C,G) Details of these drawings to better visualize the morphology of cells. The letters in (G) indicate a mitotic cell (labeled "a" by Cajal) and a fusiform or pear-like cell, described as invasive and capable of migrating due to the lack of the cellular cement (labeled "b" and shaded in blue). Adapted from Figs. 68 and 62 in (Ramón y Cajal, 1900). Histological staining (B,D) and in situ hybridization $\mathbf{F}, \mathbf{H})$ showing that Snail is expressed in dedifferentiated breast carcinomas. Note that the labeled cells closely resemble those described by Cajal. Pictures adapted from Blanco et al., 2002.

tubular EMT and the development of fibrosis in transgenic mice (Fig. 1E) and pathological Snail expression is observed in the fibrotic areas of human kidneys (Boutet et al., 2006). Until recently, renal fibrosis was thought to be provoked by the activation of interstitial fibroblasts that deposit an excess of collagen fibers. However, recent studies have shown that renal tubular epithelial cells also undergo EMT (Iwano et al., 2002). Furthermore, Snail is upregulated during the EMT suffered by hepatocytes (Valdés et al., 2002) and mesothelial cells in patients treated with peritoneal dialysis (Yañez-Mo etal., 2003). Thus, it appears that Snailgenes must be maintained silent in the adult. Snail activity is not only regulated at the level of transcription but its subcellular localization is also subject to strict control (Dominguez et al., 2003; Zhou et al., 2004). Epigenetic mechanisms are likely to be fundamental in silencing Snail since an increase in its expression can be attributed to promoter demethylation, and such increases have been correlated with the invasive properties of carcinoma cell lines (Fraga et al., 2004). Interestingly, this reactivation of Snail can be considered-as a return to the embryonic cellular state since it fulfills the same function in the adult as in the embryo, the induction of EMT.

\section{The EMT in tumor progression: A hundred years later?}

Although the magnificent contribution of Santiago Ramón y Cajal to modern Neurobiology has been well acknowledged, not that many scientists are aware that he also made significant contributions in other fields. As well as his scientific publications he also wrote some extremely successful books, the best known of which is the "Textura del sistema nervioso del hombre y los vertebrados"first published in Spanish in 1899. However, he also wrote an excellent and comprehensive Manual of Pathological
Anatomy for which he generated all the histological slides and drawings. It was in this book that he described the histopathology of many diseases in detail including an extremely interesting chapter on carcinomas. His description of the cells in mammary tumors is not only extremely detailed but also, it is illuminating and far ahead of its time in terms of his ideas about tumor malignancy. When describing the characteristics of an invasive breast tumor he mentions: "The epithelial islands are not surrounded by a basement membrane.. We must mention the fusiform, pear-like and star-like forms. . These cells are not attached to each other. This explains their invasive ability" (Ramon y Cajal, 1900). Even today, it would be difficult to better describe the epithelial cells that acquire invasive properties. These cells were superbly illustrated by Cajal and Fig. 3 includes some drawings adapted from Figures 62 and 68 of the third edition of his Manual, published in 1900. It is fascinating to see how accurately he illustrated both a differentiated and an undifferentiated and invasive human breast carcinoma (Fig. $3 \mathrm{~A}$ and $\mathrm{C}$, respectively). Interestingly enough, in infiltrating ductal breast carcinomas (IDC) Snail expression is inversely correlated with the degree of differentiation (Blanco et al., 2002). What is more, the Snail-expressing cells in these tumors are very reminiscent in location and shape to those described by Cajal more than 100 years ago (Fig. 3G-H). Thus, it seems that Cajal "understood" the process of EMT many years before its significance in tumor malignancy was established.

\section{Old views and new perspectives}

Contrary to the long established concept of the role of EMT in the formation of embryonic tissues, the significance of EMT in metastasis remains a matter of debate (Tarin, 2005). As a matter of fact, there is still little convincing evidence that this process 
occurs in human tumors. In the first place, EMT is likely to be a focal event at the initial stages of tumorigenesis and in addition, it is a dynamic process making the visualization of malignant cells with a migratory mesenchymal phenotype extremely difficult. It is very clear that for a metastasis to form, cells must colonize a distant site. During embryonic development, migratory mesenchymal cells cease their migration and differentiate when they have reached their destination (Sefton et al., 1998). They concomitantly downregulate Snail expression and undergo MET, losing their mesenchymal phenotype. This makes it also very difficult to see them in the mesenchymal state, but it is in agreement with the re-expression of E-cadherin observed in axillary lymph node metastases (Bukholm et al., 2000) and in some experimentally generated metastases (Mareel et al., 1991).

The recent development of intravital multiphoton microscopy together with novel approaches in the use of fluorescent cell markers has enabled the initial steps of tumour dissemination to be analysed in vivo in animal models. Accordingly, single carcinoma cells that have lost their epithelial polarity can be seen to migrate out of primary tumors (Wang et al., 2002; Condeelis and Segal, 2003; Fig. 1D). These data provide the first direct evidence of EMT at the initial stages of the metastatic cascade in vivo.

Another interesting concept that should be addressed is the proliferative state of the malignant cells that delaminate from the primary tumor. At first sight, one always thinks of cancer being associated with high rates of proliferation. However, there is little proliferation at the invasive front of carcinomas (Jung et al., 2001) and the dramatic cytoskeletal changes that take place during EMT are probably incompatible with cell division (Barrallo-Gimeno and Nieto, 2005). Indeed, cells transiently stop dividing before undergoing migration during embryonic development. Thus, although unregulated proliferation is fundamental for tumors to form and grow, this is not the case during their malignant phase. Interestingly, Snail blocks cell cycle progression by repressing the expression of the Cyclin Dgene and increasing the expression of the cell cycle inhibitor p21 (Vega et al., 2004). The capacity to visualize fluorescent cells disseminating from tumors has also enabled them to be isolated and purified, permitting their molecular signature to be defined. Significantly, such analyses have demonstrated that invasive cells are not proliferative (Condeelis et al., 2005) indicating that the proliferation of tumor cells can be dissociated from malignancy.

Finally, another property associated to Snail-induced EMT is the resistance of cells to apoptosis or cell death. Indeed, these cells become resistant to the loss of survival factors, the action of direct apoptotic stimuli and to genotoxic stress (Inoue et al., 2002; Perez-Losada et al., 2003; Vega et al., 2004, Kajita et al., 2004). Thus, Snail confers a selective advantage to embryonic cells migrating towards their final destination and to invasive malignant cells in their attempts to disseminate and form metastasis. Again, the in vivo purification of disseminating cells has confirmed that these cells are resistant to conventional chemotherapy (Goswami et al., 2004).

In summary, we have significantly advanced our knowledge in the last decade about the cellular processes that have been hijacked from normal developmental networks and aberrantly employed in adult pathologies. The combination of sophisticated animal models and the development of fluorescent probes and nanodevices that can be incorporated into state-of-the-art intravi- tal microscopes seem to offer promise in our fight against one of the most devastating aspects of cancer, the metastatic process, as well as against degenerative organ diseases.

\section{Acknowledgements}

I would like to thank all members of the lab for very stimulating and fruitful discussions and the Cajal Institute (CSIC) where I learned to admire Cajal's contributions and where his original drawings and slides are kept. Work in the lab is supported by Spanish Ministry of Education and Science Grants BFU2005-05772, NAN2004-09230-C04-04 and CONSOLIDER-INGENIO 2010 CSD2007-00017 and CSD2007-00023.

\section{References}

BARRALLO-GIMENO, A., and NIETO, M.A. (2005) The Snail Genes as Inducers of Cell Movement and Survival: Implications in Development and Cancer. Deve/opment. 132:3151-3161

BATLLE, E., SANCHO, E., FRANCI, C., DOMINGUEZ, D., MONFAR, M., BAULIDA, J., and GARCIA DE HERREROS, A. (2000) The Transcription Factor Snail Is a Repressor of E-Cadherin Gene Expression in Epithelial Tumour Cells. Nat Cell. Bio/2:84-89.

BELLAIRS, R. (1987). The primitive streak and the neural crest: comparable regions of cell migration? In: Developmental and Evolutionary aspects of the neural crest. Wiley and Sons, Inc. p. 123-145

BLANCO, M. J., MORENO-BUENO, G., SARRIO, D., LOCASCIO, A., CANO, A. PALACIOS, J., and NIETO, M.A. (2002) Correlation of Snail Expression with Histological Grade and Lymph Node Status in Breast Carcinomas. Oncogene. 21:3241-3246

BOUTET, A., DE FRUTOS, C. A., MAXWELL, P. H., MAYOL, M. J., ROMERO, J., and NIETO, M. A., (2006) Snail Activation Disrupts Tissue Homeostasis and Induces Fibrosis in the Adult Kidney. EMBO J. 25:5603-5613.

BOUTET, A., EstebAN, M. A., MAXWELL, P. H., and NIETO, M. A. (2007) Reactivation of Snail Genes in Renal Fibrosis and Carcinomas: A Process of Reversed Embryogenesis? Cel/ Cycle. 6:638-642.

BUKHOLM, I. K., NESLAND, J. M., and BORRESEN-DALE, A. L. (2000) ReExpression of E-Cadherin, Alpha-Catenin and Beta-Catenin, but Not of GammaCatenin, in Metastatic Tissue from Breast Cancer Patients. JPathol. 190:15-19.

CANO, A., PEREZ-MORENO, M. A., RODRIGO, I., LOCASCIO, A., BLANCO, M J., DEL BARRIO, M. G., PORTILLO, F., and NIETO, M.A. (2000) The Transcription Factor Snail Controls Epithelial-Mesenchymal Transitions by Repressing E-Cadherin Expression. Nat Cell Biol. 2:76-83.

CARMONA, R., GONZALEZ-IRIARTE, M., MACIAS, D., PEREZ-POMARES, J. M., GARCIA-GARRIDO, L., and MUNOZ-CHAPULI, R. (2000) Immunolocalization of the Transcription Factor Slug in the Developing Avian Heart. Anat Embryol (Berl) 201:103-109.

COMIJN, J., BERX, G., VERMASSEN, P., VERSCHUEREN, K., VAN GRUNSVEN, L., BRUYNEEL, E., MAREEL, M., HUYLEBROECK, D., and VAN ROY, F. (2001) The Two-Handed E Box Binding Zinc Finger Protein Sip1 Downregulates E-Cadherin and Induces Invasion. Mol Cell. 7:1267-1278.

CONDEELIS, J. AND SEGALL. (2003). Intravital imaging of cell movemet in tumors. Nat. Rev. Cancer 3: 921-930.

CONDEELIS, J., SINGER, R. H., and SEGALL, J.E., (2005) The Great Escape: When Cancer Cells Hijack the Genes for Chemotaxis and Motility. Annu Rev Cell Dev Biol. 21:695-718.

DE CRAENE, B., VAN ROY, F., and BERX, G. (2005) Unraveling Signalling Cascades for the Snail Family of Transcription Factors. Cel/ Signal. 17:535-547.

DEL BARRIO, M.G. AND NIETO M.A. (2002). Overexpression of Snail family members highlights their ability to promote chick neural crest formation. Deve/ opment 129: 1583-1593.

DOMINGUEZ, D., MONTSERRAT-SENTIS, B., VIRGOS-SOLER, A., GUAITA, S., GRUESO, J., PORTA, M., PUIG, I., BAULIDA, J., FRANCI, C., and GARCIA DE HERREROS, A. (2003) Phosphorylation Regulates the Subcellular Location and Activity of the Snail Transcriptional Repressor. Mo/Cel/ Biol. 23:5078-5089.

FRAGA, M. F., HERRANZ, M., ESPADA, J., BALLESTAR, E., PAZ, M. F., ROPERO, S., ERKEK, E., BOZDOGAN, O., PEINADO, H., NIVELEAU, A., MAO, J. H. 
BALMAIN, A., CANO, A., and ESTELLER, M. (2004) A Mouse Skin Multistage Carcinogenesis Model Reflects the Aberrant DNA Methylation Patterns of Human Tumors. Cancer Res. 64:5527-5534.

FRANCI, C., TAKKUNEN, M., DAVE, N., ALAMEDA, F., GOMEZ, S., RODRIGUEZ, R., ESCRIVA, M., MONTSERRAT-SENTIS, B., BARO, T., GARRIDO, M., BONILLA, F., VIRTANEN, I., and GARCIA DE HERREROS, A. (2006) Expression of Snail Protein in Tumor-Stroma Interface. Oncogene. 25:5134-5144.

FRITZENWANKER, J. H., SAINA, M., and TECHNAU, U. (2004) Analysis of Forkhead and Snail Expression Reveals Epithelial-Mesenchymal Transitions During Embryonic and Larval Development of Nematostella Vectensis. Dev Biol. 275:389-402.

GOSWAMI, S., WANG, W., WYCKOFF, J. B., and CONDEELIS, J. S. (2004) Breast Cancer Cells Isolated by Chemotaxis from Primary Tumors Show Increased Survival and Resistance to Chemotherapy. Cancer Res. 64:7664-7667.

HAY, E. D. (1968). Organization and fine structure of epithelium and mesenchyme in the developing chick embryo. In: Fleischmajer, R. and Billingham, R. E. Eds. Epithelial-mesenchymal interactions. Williams and Wilkins. p31-55

HAY, E. D. (1989) Theory for Epithelial-Mesenchymal Transformation Based on The «Fixed Cortex» Cell Motility Model. Cell Motil Cytoskeleton 14:455-457.

HAY, E. D. (1995) An Overview of Epithelio-Mesenchymal Transformation. Acta Anat (Basel) 154:8-20.

HEMAVATHY, K., ASHRAF, S. I., and IP, Y. P. (2000) Snail/Slug Family of Repressors: Slowly Going into the Fast Lane of Development and Cancer. Gene. 257:1-12.

INOUE, A., SEIDEL, M. G., WU, W., KAMIZONO, S., FERRANDO, A. A., BRONSON, R. T., IWASAKI, H., AKASHI, K., MORIMOTO, A., HITZLER, J. K., PESTINA T. I., JACKSON, C. W., TANAKA, R., CHONG, M. J., MCKINNON, P. J., INUKAI, T., GROSVELD, G. C., and A. LOOK, T. (2002) Slug, a Highly Conserved Zinc Finger Transcriptional Repressor, Protects Hematopoietic Progenitor Cells from Radiation-Induced Apoptosis in Vivo. Cancer Cell. 2:279-288.

IP, Y. T., and GRIDLEY, T. (2002) Cell Movements During Gastrulation: Snail Dependent and Independent Pathways. Curr Opin Genet Dev. 12:423-429.

IWANO, M., PLIETH, D., DANOFF, T. M., XUE, C., OKADA, H., and NEILSON, E. G. (2002) Evidence That Fibroblasts Derive from Epithelium During Tissue Fibrosis. J Clin Invest. 110:341-350.

JUNG, A., SCHRAUDER, M., OSWALD, U., KNOLL, C., SELLBERG, P., PALMQVIST, R., NIEDOBITEK, G., BRABLETZ, T., and KIRCHNER, T. (2001) The Invasion Front of Human Colorectal Adenocarcinomas Shows Co-Localization of Nuclear Beta-Catenin, Cyclin D1, and P16ink4a and Is a Region of Low Proliferation. Am J Pathol. 159:1613-1617.

KAJITA, M., MCCLINIC, K. N., and WADE, P. A. (2004) Aberrant Expression of the Transcription Factors Snail and Slug Alters the Response to Genotoxic Stress. $\mathrm{Mol}$ Cell Biol. 24:7559-7566.

LOCASCIO, A., MANZANARES, M., BLANCO, M.J. AND NIETO, M.A. (2002). Modularity and reshuffling of Snail and Slug expression during vertebrate evolution. Proc. Natl. Acad. Sci. USA. 99: 16841-16846.

KUPHAL, S., PALM, H. G., POSER, I., and BOSSERHOFF, A. K. (2005) SnailRegulated Genes in Malignant Melanoma. Melanoma Res. 15:305-313.

MANZANARES, M., and NIETO, M.A. (2003) A Celebration of the New Head and an Evaluation of the New Mouth. Neuron. 37:895-898.

MAREEL, M. M., BEHRENS, J., BIRCHMEIER, W., DE BRUYNE, G. K., VLEMINCKX, K., HOOGEWIJS, A., FIERS, W. C., and VAN ROY, F. M. (1991) Down-Regulation of E-Cadherin Expression in Madin Darby Canine Kidney (Mdck) Cells inside Tumors of Nude Mice. Int J Cancer 47:922-928.

MARTÍNEZ-ÁLVAREZ, C., BLANCO, M.J., PÉREZ, R., APARICIO, M., RESEL, E., RABADÁN, M.A., MARTÍNEZ, T., AND NIETO, M.A. (2004). Snail family members and cell survival in physiological and pathological cleft palates. Dev. Biol. 265: 207-218.

MIYOSHI, A., KITAJIMA, Y., KIDO, S., SHIMONISHI, T., MATSUYAMA,S., KITAHARA, K., and MIYAZAKI, K. (2005) Snail Accelerates Cancer Invasion by Upregulating Mmp Expression and Is Associated with Poor Prognosis of Hepatocellular Carcinoma. Br J Cancer. 92:252-258.

MOODY, S. E., PEREZ, D., PAN, T. C., SARKISIAN, C. J., PORTOCARRERO, C. P., STERNER, C. J., NOTORFRANCESCO, K. L., CARDIFF, R. D., and CHODOSH, L.A. (2005) The Transcriptional Repressor Snail Promotes Mammary Tumor Recurrence. Cancer Cell. 8:197-209.
MORENO-BUENO, G., CUBILLO, E., SARRIO, D., PEINADO, H., RODRIGUEZ PINILLA, S. M., VILLA, S., BOLOS, V., JORDA, M., FABRA, A., PORTILLO, F., PALACIOS, J., and CANO, A. (2006) Genetic Profiling of Epithelial Cells Expressing E-Cadherin Repressors Reveals a Distinct Role for Snail, Slug, and E47 Factors in Epithelial-Mesenchymal Transition. Cancer Res. 66:9543-9556.

MURRAY, S. A., ORAM, K. F., and GRIDLEY, T. (2007) Multiple Functions of Snail Family Genes During Palate Development in Mice. Development. 134:17891797.

NAVARRO, P., LOZANO, E., and CANO, A. (1993) Expression of E- or P-Cadherin Is Not Sufficient to Modify the Morphology and the Tumorigenic Behavior of Murine Spindle Carcinoma Cells. Possible Involvement of Plakoglobin. J Cell Sci. 105 (Pt 4):923-934.

NIETO, M. A. (2002) The Snail Superfamily of Zinc-Finger Transcription Factors. Nat Rev Mol Cell Bio/3:155-166.

NIETO, M. A., SARGENT, M. G., WILKINSON, D. G., and COOKE, J. (1994) Control of Cell Behavior During Vertebrate Development by Slug, a Zinc Finger Gene. Science. 264:835-839

OLMEDA, D., JORDA, M., PEINADO, H., FABRA, A., and CANO, A. (2007) Snail Silencing Effectively Suppresses Tumour Growth and Invasiveness. Oncogene. 26:1862-1874

PALMER, H. G., LARRIBA, M. J., GARCIA, J. M., ORDONEZ-MORAN, P., PENA, C., PEIRO, S., PUIG, I., RODRIGUEZ, R., DE LA FUENTE, R., BERNAD, A., POLLAN, M., BONILLA, F., GAMALLO, C., DE HERREROS, A. G., and MUNOZ, A. (2004) The Transcription Factor Snail Represses Vitamin D Receptor Expression and Responsiveness in Human Colon Cancer. Nat Med. 10:917-919.

PEINADO, H., BALLESTAR, E., ESTELLER, M. and CANO, A. (2004a) Snail Mediates E-Cadherin Repression by the Recruitment of the Sin3a/Histone Deacetylase 1 (Hdac1)/Hdac2 Complex. Mol Cell Biol. 24:306-319.

PEINADO, H., DEL CARMEN IGLESIAS-DE LA CRUZ, M., OLMEDA, D., CSISZAR K., FONG, K. S., VEGA, S., NIETO, M. A., CANO, A., and PORTILLO, F. (2005) A Molecular Role for Lysyl Oxidase-Like 2 Enzyme in Snail Regulation and Tumor Progression. EMBO J. 24:3446-3458.

PEINADO, H., MARIN, F., CUBILLO, E., STARK, H. J., FUSENIG, N., NIETO, M.A., and CANO, A. (2004b) Snail and E47 Repressors of E-Cadherin Induce Distinct Invasive and Angiogenic Properties in Vivo. J Cell Sci. 117:2827-2839.

PEINADO, H., OLMEDA, D., and CANO, A. (2007) Snail, Zeb and Bhlh Factors in Tumour Progression: An Alliance against the Epithelial Phenotype? Nat Rev Cancer. 7:415-428.

Perez-losada, J., SANCheZ-Martin, M., PereZ-CARo, M., PEREZMANCERA, P. A., and SANCHEZ-GARCIA,I. (2003) The Radioresistance Biological Function of the Scf/Kit Signaling Pathway Is Mediated by the ZincFinger Transcription Factor Slug. Oncogene. 22:4205-4211.

PEREZ-MANCERA, P. A., GONZALEZ-HERRERO, I., PEREZ-CARO, M., GUTIERREZ-CIANCA, N., FLORES, T., GUTIERREZ-ADAN, A., PINTADO, B., SANCHEZ-MARTIN, M., and SANCHEZ-GARCIA, I. (2005a) Slug in Cancer Development. Oncogene. 24:3073-3082.

PEREZ-MANCERA, P. A., PEREZ-CARO, M., GONZALEZ-HERRERO, I., FLORES, T., ORFAO, A., DE HERREROS, A. G., GUTIERREZ-ADAN, A., PINTADO, B., SAGRERA, A., SANCHEZ-MARTIN, M., and SANCHEZ-GARCIA, I. (2005b) Cancer Development Induced by Graded Expression of Snail in Mice. Hum Mol Genet. 14:3449-3461.

PEREZ-MORENO, M. A., LOCASCIO, A., RODRIGO, I., DHONDT, G., PORTILLO F., NIETO, M. A., and CANO, A. (2001) A New Role for E12/E47 in the Repression of E-Cadherin Expression and Epithelial-Mesenchymal Transitions. J Biol Chem. 276:27424-27431.

PERL, A. K., WILGENBUS, P., DAHL, U., SEMB, H., and CHRISTOFORI, G. (1998) A Causal Role for E-Cadherin in the Transition from Adenoma to Carcinoma. Nature. 392:190-193.

RAMON Y CAJAL, S. (1900). Manual de Anatomía Patológica.

RAMON Y CAJAL, S. (1899). Textura del sistema nervioso del hombre y los vertebrados. Imprenta y Librería de Nicolás Moya. Madrid.

ROMANO, L. A., and RUNYAN, R. B. (2000) Slug Is an Essential Target of Tgfbeta2 Signaling in the Developing Chicken Heart. Dev Biol. 223:91-102.

ROSIVATZ, E., BECKER, I., SPECHT, K., FRICKE, E., LUBER, B., BUSCH, R. HOFLER, H., and BECKER, K. F. (2002) Differential Expression of the Epithe- 
lial-Mesenchymal Transition Regulators Snail, Sip1, and Twist in Gastric Cancer. Am J Pathol. 161:1881-1891.

SAITO, T., ODA, Y., KAWAGUCHI, K., SUGIMACHI, K., YAMAMOTO, H., TATEISHI, N., TANAKA, K., MATSUDA, S., IWAMOTO, Y., LADANYI, M., and TSUNEYOSHI, M. (2004) E-Cadherin Mutation and Snail Overexpression as Alternative Mechanisms of E-Cadherin Inactivation in Synovial Sarcoma. Oncogene. 23:8629-8638.

SEFTON, M., SANCHEZ, S., and NIETO, M. A. (1998) Conserved and Divergent Roles for Members of the Snail Family of Transcription Factors in the Chick and Mouse Embryo. Development. 125:3111-3121.

TARIN, D., THOMPSON, E. W., and NEWGREEN, D. F. (2005) The Fallacy of Epithelial Mesenchymal Transition in Neoplasia. Cancer Res. 65:5996-6000; discussion 00-1.

THIERY, J.P. (1984) Mechanisms of Cell Migration in the Vertebrate Embryo. Cell Differ. 15:1-15.

THIERY, J. P. (2002) Epithelial-Mesenchymal Transitions in Tumour Progression. Nat Rev Cancer. 2:442-454.

THOMPSON, E. W., NEWGREEN, D. F., and TARIN, D. (2005) Carcinoma Invasion and Metastasis: A Role for Epithelial-Mesenchymal Transition? Cancer Res. 65:5991-5; discussion 95.

TIMMERMAN, L. A., GREGO-BESSA, J., RAYA, A., BERTRAN, E., PEREZPOMARES, J. M., DIEZ, J., ARANDA, S., PALOMO, S., MCCORMICK, F., IZPISUA-BELMONTE, J. C., and DE LA POMPA, J. L. (2004) Notch Promotes Epithelial-Mesenchymal Transition During Cardiac Development and Oncogenic Transformation. Genes Dev. 18:99-115.

VAldes, F., Alvarez, A. M., locascio, A., VegA, S., herRerA, B., FERNANDEZ, M., BENITO, M., NIETO, M. A., and FABREGAT, I. (2002) The
Epithelial Mesenchymal Transition Confers Resistance to the Apoptotic Effects of Transforming Growth Factor Beta in Fetal Rat Hepatocytes. Mol Cancer Res. 1:68-78.

VEGA, S., MORALES, A. V., OCANA, O. H., VALDES, F., FABREGAT, I., and NIETO, M. A. (2004) Snail Blocks the Cell Cycle and Confers Resistance to Cell Death. Genes Dev. 18:1131-1143.

VELTMAAT, J.M., ORELIO, C.C., WARD-VAN OOSTWAARD, D., VAN ROOIJEN, M.A., MUMMERY, C,L, AND DEFIZE, L.H. (2000). Snail is an immediate early target gene of parathyroid hormone related peptide signaling in parietal endoderm formation. Int. J. Dev. Biol. 44:297-307.

WANG, W., WYCKOFF, J. B., FROHLICH, V. C., OLEYNIKOV, Y., HUTTELMAIER, S., ZAVADIL, J., CERMAK, L., BOTTINGER, E. P., SINGER, R. H., WHITE, J. G., SEGALL, J. E., and CONDEELIS, J. S. (2002) Single Cell Behavior in Metastatic Primary Mammary Tumors Correlated with Gene Expression Patterns Revealed by Molecular Profiling. Cancer Res. 62:6278-6288.

YANEZ-MO, M., LARA-PEZZI, E., SELGAS, R., RAMIREZ-HUESCA, M. DOMINGUEZ-JIMENEZ, C., JIMENEZ-HEFFERNAN, J. A., AGUILERA, A., SANCHEZ-TOMERO, J. A., BAJO, M. A., ALVAREZ, V., CASTRO, M. A., DEL PESO, G., CIRUJEDA, A., GAMALLO, C., SANCHEZ-MADRID, F., and LOPEZCABRERA, M. (2003) Peritoneal Dialysis and Epithelial-to-Mesenchymal Transition of Mesothelial Cells. N Eng/ J Med. 348:403-413.

YANG, J., MANI, S. A., DONAHER, J. L., RAMASWAMY, S., ITZYKSON, R. A., COME, C., SAVAGNER, P., GITELMAN, I., RICHARDSON, A., and WEINBERG, R. A. (2004) Twist, a Master Regulator of Morphogenesis, Plays an Essential Role in Tumor Metastasis. Cell. 117:927-939.

ZHOU, B. P., DENG, J., XIA, W., XU, J., LI, Y. M., GUNDUZ, M., and HUNG, M. C (2004) Dual Regulation of Snail by Gsk-3beta-Mediated Phosphorylation in Control of Epithelial-Mesenchymal Transition. Nat Cel/ Biol. 6:931-940. 


\section{Further Related Reading, published previously in the Int. J. Dev. Biol.}

See our recent Special Issue Fertilization, in honor of David L. Garbers and edited by Paul M. Wassarman and Victor D. Vacquier at: http://www.ijdb.ehu.es/web/contents.php?vol=52\&issue=5-6

See our recent Special Issue Ear Development edited by Fernando Giraldez and Bernd Fritzsch at: http://www.ijdb.ehu.es/web/contents.php?vol=51\&issue=6-7

Tbx1 is expressed at multiple sites of epithelial-mesenchymal interaction during early development of the facial complex Maria Zoupa, Maisa Seppala, Thimios Mitsiadis and Martyn T. Cobourne Int. J. Dev. Biol. (2006) 50: 504-510

Migration of neural crest-derived enteric nervous system precursor cells to and within the gastrointestinal tract Alan J. Burns

Int. J. Dev. Biol. (2005) 49: 143-150

Regulation of cell adhesion and migration in lens development

Peggy S. Zelenka

Int. J. Dev. Biol. (2004) 48: 857-865

Primordial germ cell migration

Kathleen Molyneaux and Christopher Wylie

Int. J. Dev. Biol. (2004) 48: 537-543

The migration and differentiation of a chemist entangled in developmental and cancer biology. An interview with Jean-Paul Thiery.

Fred T. Bosman

Int. J. Dev. Biol. (2004) 48: 529-535

From here to there; a life based on migration. An interview with Isaiah J. Fidler Ian R. Hart

Int. J. Dev. Biol. (2004) 48: 457-462

Collective cell migration in morphogenesis and cancer

Peter Friedl, Yael Hegerfeldt and Miriam Tusch

Int. J. Dev. Biol. (2004) 48: 441-449

Cytoskeletal mechanisms responsible for invasive migration of neoplastic cells Jury M. Vasiliev

Int. J. Dev. Biol. (2004) 48: 425-439

Regulation of cell migration during tracheal development in Drosophila melanogaster.

Valérie Petit, Carlos Ribeiro, Andreas Ebner and Markus Affolter

Int. J. Dev. Biol. (2002) 46: 125-132

Developmental expression of Smad1-7 suggests critical function of TGF-beta/BMP signaling in regulating epithelial-mesenchymal interaction during tooth morphogenesis.

Xun Xu, Lesley Jeong, Jun Han, Yoshihiro Ito, Pablo Bringas and Yang Chai Int. J. Dev. Biol. (2003) 47: 31-39

Patterning parameters associated with the branching of the ureteric bud regulated by epithelial-mesenchymal interactions.

Yanfeng Lin, Shaobing Zhang, Juha Tuukkanen, Hellevi Peltoketo, Taina Pihlajaniemi and Seppo Vainio

Int. J. Dev. Biol. (2003) 47: 3-13

Snail is an immediate early target gene of parathyroid hormone related peptide signaling in parietal endoderm formation.

J M Veltmaat, C C Orelio, D Ward-Van Oostwaard, M A Van Rooijen, C L Mummery and L H Defize

Int. J. Dev. Biol. (2000) 44: 297-307
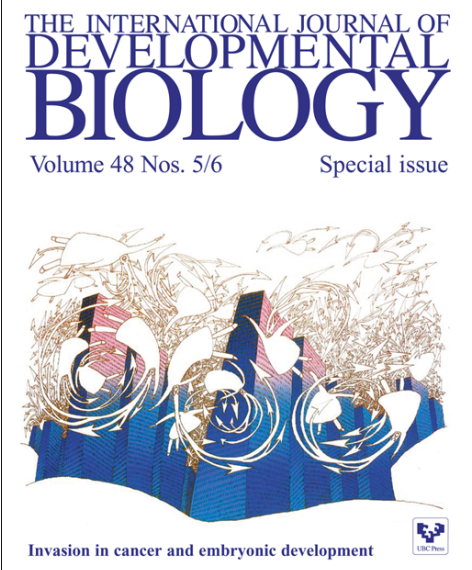

5 yr ISI Impact Factor $(2008)=3.271$

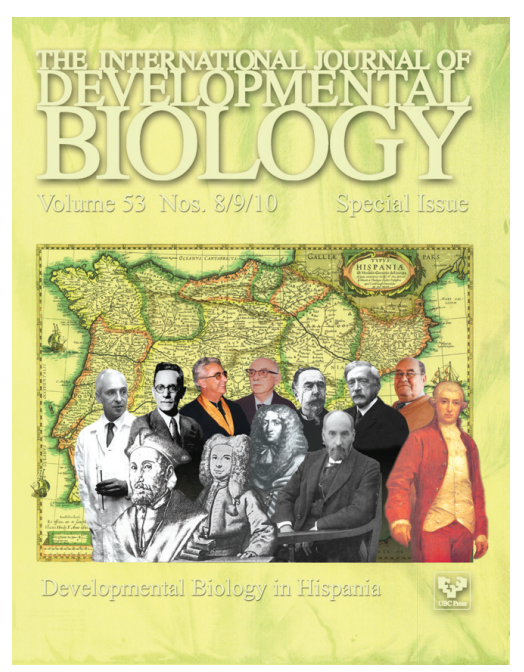

